\title{
タンパク質の解離性 $(\mathbb{I})$
}

永沢満*

\section{1. 緒言}

タンパク質はよく知られているように一種の両性電解 質であり， 1 分子上に多数の酸性拉よび塩基性の解離基 をもっている。それらの解離基の種類, 数の分析がタン パク質研究上にもっている重要性は特に説明を要しな い。その分析には近年発達したアミノ酸分析法も用いら れるが，その他にタンパク質の電位差㴼定曲線の解析む 非常に有力な方法である。滴定曲線の解析法は Tanford はじめ多くの人々の努力によって近年ほぼ確定しアミノ 酸分析の結果と非常に良い一致を示すようになった。し かし，滴定曲線の解析はこのよ5に解離基の分析に用い られるばかりでなく，溶液中におけりるタンパク質分子の 物理化学的性質, あるいは変性などの物理化学的変化を 理解するために重要な役割をるっている。タンパク質分 子の有する有離電荷の数, あるいは, その解離基と他の イオン, 分子, あるいは他の固定解離基との相互作用な ぞが解離曲線の解析によって明らかにされる。さらにま た，将来タンパク質分子表面上火打ける解離基の状態を 知る手がかりを得る可能性むあるかるしれない。

しかしタンパク質の解離性は, これら多数の種類の基 の解離の重盢, 相互作用によってきわめて複雑でめる。 たとえば負に帯電した解離基は酸基の解離を抑制するよ うに作用し，その反刘に負に带電した解離基は酸基の解 離を容易ならしめるように㗢く。したがってタンパク質 分子が全体として負の荷電を有している場合には，その 分子中の酸基の見かけの解離定数はその解離基が 1 個だ け単独に存在している場合の固有解離定数より小さくな り，タンパク分子が陽に帯電している場合にはそ逆で ある。タンパク質の解離性を論ずるにはこのような，い わゆる解離基間あるいはイオンふんい気との電気的相互 作用を理解しなければならず，かなりむずかしい問題で ある。この方面の研究は, 1924 年 Linderstrom-Lang ${ }^{1}$ によってよく知られた理論が出されて以来活発になって きたが, 彼の理諭にしてもその後発表せられた理論にし てもいくつかの重大な仮定を含み，その適用炕当っては 十分なる注意がはらわれねばならない。

\footnotetext{
$*$ 名古屋大学工学部教授・工博
}

本小文は，これらタンパク質の電位差滴定曲線に関す る理論的, 実験的研究の現状を, 1950 年前後より活発 に行なわれた高分子電解質に関する理論的研究を参考に しつつ解説しようとするものである。タンパク質の解離 性については, すでに Edsall ${ }^{2)}$ 㧊よび Tanford ${ }^{3)}$ の著 者に詳しい解説がある。おわせて読まれることが望をし い。また解離基の種類・数の決定についてはここでは祥 説せずに，単に以後の理解を容易にするための予借知識 を与える程度にとどめるゆえ, 必要の方々は Tanford らの論文を参考にされたい。

\section{2. タンパク質の電位差滴定曲線と解離基の分析}

最初に理解を容易にするために, 合成両性電解質であ るところの Methacrylic acid と Dimethylamino ethyl methacrylate の共重合体の実験例を用いて, 滴定曲線 からいかにして - $\mathrm{COOH}$ の数, 岁るいは Amino 基の 数を決定するかを説明しょう。

試料溶液を強酸強塩基型イオン交換樹脂の Mixed bed を通して完全に脱塩すると，タンパク分子， $\mathrm{H}^{+}$特よび $\mathrm{OH}^{-}$の他には無機イオンは全く含まない溶液, いわゆ る, Iso-ionic solution が得られる。この溶液に必要な らば適当な濃度の中性塩を加えて, 酸兴るいはアルカリ

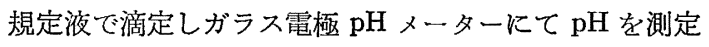

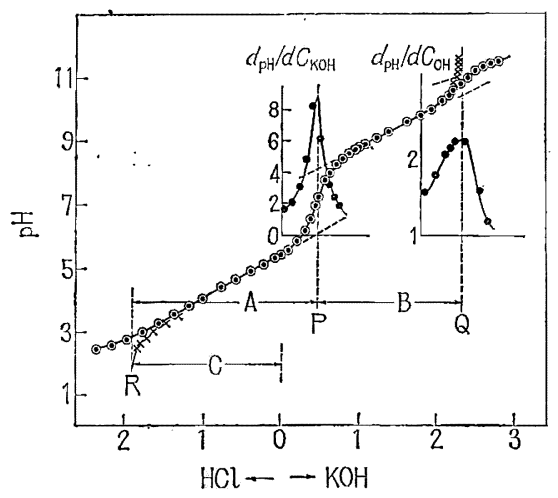

○ $\mathrm{pH}, \times \mathrm{H}^{+}$あるい法 $\mathrm{OH}^{-}$の結合量

第 1 図 Methacrylic acid と Dimethylamineethyl-methacrylate の共重合体の 電位差滴定曲線 ${ }^{21)}$ 
すれば容易に電位差滴定曲線（第 1 図）が得られる。無 塩系に打いては試料濃度の影響が現われるが，添加塩濃 度が高ければ試料濃度の影響はほとんで無視できる。

Iso-ionic solution 中では分子は-OOC-O- $\mathrm{NH}_{3}{ }^{+}$の いわゆる“Zwitter-ion”の状態となって牧り，その $\mathrm{pH}$ から 1 分子の有する荷電を計算してみると（この共 重合体のみならずすべての Iso-ionic protein の溶液中 で）ほとんぞ0であることがわがるすなわち解離して いる-COO- の数と $-\mathrm{NH}_{3}{ }^{+}$の数とはほとんど相等しい。 しかも $-\mathrm{NH}_{3}+$ の解離定数 $\left(p K_{0}=9 \sim 10\right)$ を考光れば Iso-ionic point においては $-\mathrm{NH}_{3}{ }^{+}$はほとんぞ完全に 解離し, $-\mathrm{COOH}$ は $-\mathrm{NH}_{3}{ }^{+}$に等しい数だけ解離して残 りは不解離状態になっていることがわかる。したがって Iso-ionic solution を $\mathrm{NaOH}$ にて滴定すれば, 最初未 解離の $-\mathrm{COOH}$ の中和が進行し，つづいて解離していた $-\mathrm{NH}_{3}+k$ 詨する $\mathrm{OH}^{-}$の結合が起こる。この試料の場 合には $-\mathrm{COOH}$ と $-\mathrm{NH}_{2}$ の解離定数が十分離れている ために, $-\mathrm{COOH}$ の中和完了の後に $-\mathrm{NH}_{3}{ }^{+}$の不解離が 始まり, 第 1 図の $\mathrm{P}$ 点に拈いて $\mathrm{pH}$ の不連続が観察さ れる。さらに $\mathrm{NaOH}$ を添加すれば, すべての $-\mathrm{NH}_{3}{ }^{+}$ が未解離状態の $-\mathrm{NH}_{2}$ になり，そこで再び $\mathrm{pH}$ の不連 続が観察される。したがって第 1 図の B の值が分子中 の $-\mathrm{NH}_{2}$ の量となる。

次に, 試料の Iso-ionic solution を $\mathrm{HCl}$ にて滴定す ると $-\mathrm{NH}_{3}+$ には何の変化もなく, 解離していたーCOOに $\mathrm{H}^{+}$が結合し $\mathrm{R}$ 点に执いてずべての $-\mathrm{COOH}$ が末 解離状態となる。したがって第 1 図のA が分子内の - $\mathrm{COOH}$ の数となり, C は Iso-ionic point で解離して いた - $\mathrm{COO}^{-}$の数, すなわち $-\mathrm{NH}_{3}{ }^{+}$基の全数となる。 $\mathrm{R}$ 点に抢いても $\mathrm{pH}$ の不連続が見られるはずであるが， $\mathrm{pH}$ が低いため観察されるほどにはならない。そのため $\mathrm{R}$ 点の決定は通常 Tanford ${ }^{4}$ により用いられている $\mathrm{H}^{+}$ の吸着量を利用する方法によって決定される。すなわち 遊離 $\mathrm{H}^{+}$濃度 $\left.\mathrm{H}^{+}\right]$は $\mathrm{pH}$ 测定值から次式によって計

$$
\mathrm{pH}=-\log \gamma\left[\mathrm{H}^{+}\right]
$$

算されるから，タンパク質分子に吸着された $\mathrm{H}^{+}$の量は 加兄られた $\mathrm{H}^{+}$の量から遊離している $\mathrm{H}^{+}$の量を差し 引いて求められる。ここで $\mathrm{H}^{+}$の活量係数 $r$ はタンパ ク質の有無に関せず変化しないと仮定して適当な表から 求められる。このようにして求めた結合 $\mathrm{H}^{+}$の量は同じ く第 1 図に $\mathrm{pH}$ に対してプロットしてある。 $\mathrm{pH}$ 無限小 の極限に抢ける結合 $\mathrm{H}^{+}$の量が Iso-ionic point 飞拉 いて解離していた $-\mathrm{COOH}$ の量を示す。 Q 点も同様に して $\mathrm{OH}^{-}$結合量から決定できる。

天然タンパク質の場合にも同様の考えによって分析で きるが，天然タンパク質の場合には解離基の種類が単に 酸, 塩基各 1 種類ずつに限らず，数種類の異なった解離 定数をるつ基の混合物であるため問題ははるかに複雑で
ある。たとえば $\beta$-Lactoglobulin ${ }^{5)}$ の滴定曲線を示せば 第 2 図のごとくである。第 1 図の場合と同じく Maxi-

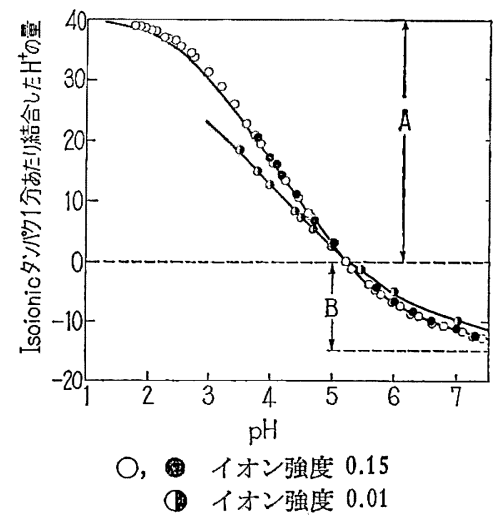

第 2 図 $\beta$-Lactoglobulin の滴定曲線(

mum acid binding A は全塩基性解離基量となり, B は全酸基を示す。この全塩基量抢よび全酸量からタン パク質中のそれぞれの基の数を決定するためには，それ ぞれの基の固有解離定数を考慮して Trial and error calculation により求めなければならない。また必要に 応じて HCHO などを加穴てある種の解離基の解離を特 さえることもある。Phenolic group などは $p K_{0}$ がも っとアルカリ側にあり第 2 図の滴定には関与していない ことにも注意されねばならない。Phenolic groupを求 わるためにはさらにアルカリ側の滴定曲線を調べねばな らない。解離基の分析法について述べるのは本文の目的 ではないから，詳細は Tanford ${ }^{2,3)}$ らの論文を参考とさ れたい。

このようにして決定された解離基の数はアミノ酸分析 によって決定された值ときわめて良い一致を示している (第 1 表)。

第 1 表 $\beta$-Lactoglobulin の解離基 ${ }^{5)}$

\begin{tabular}{|c|c|c|}
\hline & $\begin{array}{l}\text { アミノ酸 } \\
\text { 分析による }\end{array}$ & $\begin{array}{c}\text { 電位差滴定 } \\
\text { による }\end{array}$ \\
\hline$\alpha-\mathrm{COOH}$ & 2 & 2 \\
\hline$\beta, \gamma-\mathrm{COOH}$ (normal) & 50 & 49 \\
\hline$\beta, \gamma-\mathrm{COOH}$ (anomalous) & 50 & 2 \\
\hline Imidazole & 4 & 4 \\
\hline$\alpha-\mathrm{NH}_{2}$ & 2 & 2 \\
\hline$\epsilon-\mathrm{NH}_{2}$ & 27 & 28 \\
\hline Phenolic & 7 & 6 \\
\hline Sulfhydryl & 3 & $\ldots$ \\
\hline Guanidyl & 6 & 6 \\
\hline Total cationic & 39 & 40 \\
\hline
\end{tabular}

\section{3. 滴定曲線の理論}

前節において滴定曲線から滴定にかかる基を分析する 
方法を述べた。このようにして決定された基の数は溶液 中の添加中性塩（たとえば $\mathrm{NaCl}, \mathrm{KCl}$ な゙゙)の浱度に は無関係であるが，滴定曲線の形自身は第 2 図に見られ るようにかなり塩濃度によって变化する。タンパク質上 の同じ種類の解離基（たと亲ばグルタミン酸の- $\mathrm{COOH}$ ) は 1 個 1 個独立の場合以は同じ固有解離定数をもってい るが，タンパク分子上の关の基の解離定数を測定してみ ると, 条件によって異なった值が得られ, 見かけの解離 定数はタンパク質の有する荷電の量に応じて変化する。 これはすで解離した基が未解離の基の解離性に静電気 的影響を与えるためでめる。中性塩を添加するとこの静 電気的影響が遮断されるために解離定数の変化が現わ れ，滴定曲線が変化するのである。このようなタンパク 質の有する荷電による解離定数の变化, 女るい性塩 添加による変化を静電気的相互作用の立場から定量的に 説明しょうというのがこの方面の研究である。

今, 例として $-\mathrm{COOH}$ をとろう。- $\mathrm{COOH}$ は水溶液 中で次のよ 5 に解離し

$$
-\mathrm{COOH} \rightleftarrows-\mathrm{COO}^{-}+\mathrm{H}^{+}
$$

その熱力学的解離定数 $K_{a}$ 忙

$$
K_{a}=\frac{\left(-\mathrm{COO}^{-}\right)\left(\mathrm{H}^{+}\right)}{(-\mathrm{COOH})}
$$

で与えられる。ここで（）は活量を意味し，次に現われ る [ ] は分析濃度を示すものとする。- $\mathrm{COOH},-\mathrm{COO}^{-}$ は分析によって濃度決定されるが，その活量を求めるこ とができないゆ光，通常次の実用的固有解離定数 (Intrinsic ionization constant) $K_{0}$ が定義され用いられ る。

$$
K_{0}=\frac{\left[-\mathrm{COO}^{-}\right]\left(\mathrm{H}^{+}\right)}{[-\mathrm{COOH}]}
$$

$K_{a}$ はもらろん定数であるが， $K_{0}$ もまたほとんど定数 とみなせるし，添加塩の影響もほとんど受けない。

今解離度を $\alpha$ で表わすと

$$
\alpha=\frac{\left[-\mathrm{COO}^{-}\right]}{\left[-\mathrm{COO}^{-}\right]+[-\mathrm{COOH}]}
$$

であるから (1) 式より

$$
\begin{aligned}
& p H=p K_{0}-\log \frac{1-\alpha}{\alpha} \\
& p K_{0}=-\log K_{0}
\end{aligned}
$$

ここで $p K_{0}\left(\right.$ 正しくは $p K_{a}$ ) は $-\mathrm{COOH}$ から $\mathrm{H}^{+}$を無 限の遠くに引き離すに要する仕事 $\Delta F_{0}$ と次の関係にあ る。

$$
-\ln K_{0}=\frac{\Delta F_{0}}{R T}
$$

タンパク質のごとく 1 分子上に多数の解離基を有する 場合には, 解離に要する仕事にはこの $\Delta F_{0}$ の他に解離 した基の 静電的引力（あるいは哌力）に対してなされる
仕事を考えなければならない。

\section{3-1. Katchalsky, Gillis $の$ 理論()}

今分子が $p$ 個の $-\mathrm{COOH}$ を含む高分子酸であったと 仮定しょう。溶液中の $-\mathrm{COOH}$ のモル数を $c$, 加兄ら れたアルカリのモル数を $b$ とすれば, 中和度 $\alpha$ は $b / c$ で与兊られる。また $c / p$ は高分子酸のモル数となる。中 和度 $\alpha$ は各分子の間に $0 \sim 1$ の異なった中和度のスペ クトルとして分布せられる。今 $A_{\nu} を \nu$ 個の $-\mathrm{COOH}$ がイオン化した分子の濃度とすれば

$$
\left\{\begin{array}{l}
\sum_{\nu=0}^{p} A_{\nu}=\frac{c}{p} \\
\sum_{\nu=1}^{p} \nu A_{\nu}=b
\end{array}\right.
$$

解離の各ステップごとに

$$
\frac{\left(\mathrm{H}^{+}\right) \cdot A_{\nu}}{A_{\nu-1}}=K_{\nu} \quad \nu=1,2 \ldots \ldots p
$$

が成立している。(ע-1) 個の - $\mathrm{COOH}$ が解離している 分子から $\mathrm{H}^{+}$が出てゆく速度は $v_{1}(p-\nu+1) A_{\nu-1}\left(v_{1}\right.$ : 定 数)であり，逆に $\mathrm{H}^{+}$がン個の解離した分子に結合す る速度は $v_{2} \nu\left(\mathrm{H}^{+}\right) \cdot A_{\nu}$ である。平衡に特いては

$$
v_{1}(p-\nu+1) A_{\nu-1}=v_{2} \cdot \nu \cdot\left(\mathrm{H}^{+}\right) \cdot A_{\nu}
$$

すなわら

$$
\frac{\left(\mathrm{H}^{+}\right) \cdot A_{\nu}}{A_{\nu-1}}=K_{\nu}=\frac{v_{1}}{v_{2}} \frac{p-\nu+1}{\nu}=K_{\nu}{ }^{\prime} \frac{p-\nu+1}{\nu}
$$

$K_{\nu}{ }^{\prime}$ は $(\nu-1)$ の解離した分子中の 1 個の $-\mathrm{COOH}$ の解 離定数である。すなわち

$$
\Delta F_{\nu}{ }^{\prime}=-R T \ln K_{\nu}{ }^{\prime}
$$

そ数けば $\Delta F_{\nu}^{\prime}$ はとの分子中の 1 個の $-\mathrm{COOH}$ の解離の 自由エネルギーである。 $\Delta F_{\nu}^{\prime}$ はすで述べたごとく二つ の独立の項によってできている。一つはそのーCOOH か ら $\mathrm{H}^{+}$を引き離す必要な仕事 $A F_{0}$ であり, 他の一つ はその分子上の他の解離した基からくる静電気的引力に さからってなされる仕事 $\Delta F_{\nu}$ である。

$$
\begin{array}{lc} 
& \Delta F_{\nu}{ }^{\prime}=\Delta F_{0}+\Delta F_{\nu} \\
\text { ここで } & \Delta F_{0}=-R T \ln K_{0} \\
\text { また } & K_{\nu}{ }^{\prime}=K_{0} \exp -\frac{\Delta F_{\nu}}{R T}
\end{array}
$$

したがって

$$
K_{\nu}=K_{0} \frac{p-\nu+1}{\nu} \mathrm{e}^{-\Delta F_{\nu} / R T}
$$

(5) 式と（12）式より $A_{\nu}$ を計算し（4）式に代入すれば

$$
\frac{b p}{c}=\frac{\sum \nu A_{\nu}}{\sum A_{\nu}}=\frac{\sum \nu\left[\begin{array}{c}
K_{0} \\
\left(\mathrm{H}^{+}\right)
\end{array}\right]^{\nu}\left(\begin{array}{l}
p \\
\nu
\end{array}\right) \mathrm{e}^{-\Sigma \Delta F_{\nu} / R T}}{\sum\left[\frac{K_{0}}{\left(\mathrm{H}^{+}\right)}\right]^{\nu}\left(\begin{array}{l}
p \\
\nu
\end{array}\right) \mathrm{e}^{-\Sigma \Delta F_{\nu} / R T}}
$$


ここで $\quad\left(\begin{array}{l}p \\ \nu\end{array}\right)=\frac{p(p-1) \ldots(p-\nu+1)}{1,2 \ldots \nu}$

(13) 式の分子分母の $\Sigma$ は ゆ光（13）式を次の近似式で括きか觉ることができる。

$$
\frac{b p}{c}=\frac{\nu_{\max } \cdot\left(A_{\nu}\right)_{\max }}{\left(A_{\nu}\right)_{\max }}=\nu_{\max }
$$

$\nu_{\text {max }}$ は $A_{\nu}=A_{\nu-1}$ の条件上り求めら結局次式が得ら れる。

$$
\frac{K_{0}}{\left(\mathrm{H}^{+}\right)} \frac{p-\nu_{\max }+1}{\nu_{\max }} \mathrm{e}^{-\lrcorner F_{\nu} / R T=1}
$$

ここで $\nu_{\max } / p=b / c$ であるから $p \gg 1$ の場合には

$$
\left(\mathrm{H}^{+}\right)=K_{0} \frac{c-b}{b} \mathrm{e}^{-\Delta F_{\nu} / R T}
$$

すなわち

$$
p H=p K_{0}-\log \frac{1-\alpha}{\alpha}+0.434 \frac{\Delta F_{\nu}}{R T}
$$

ここで $\Delta F_{\nu}$ は $\mathrm{H}^{+}$を解離させる際に, ン個の解離した 基からの静電気的引力にさからってなさなければならな い仕事であり，分子の有する電気的自由エネルギーを $F_{\nu}$ で表わせば

$$
\Delta F_{\nu}=\frac{\partial F_{\nu}}{\partial \nu}
$$

であり，また分子表面の(解離しょうとしている $\mathrm{COOH}$ の位置の）静電ポテルシャルを $\Psi_{b}$ とすれば

$$
\Delta F_{\nu}=\mathrm{e} \Psi_{b}
$$

で表わされる。またこの節の初めに述べた見かけの解離 定数, すな方占次の反応の平均解離定数 $K$ は

$$
\begin{aligned}
& \left(P H_{\nu}\right)^{0} \rightleftarrows P^{-\nu}+\nu \mathrm{H}^{+} \\
& \frac{A_{\nu} \cdot\left(\mathrm{H}^{+}\right)^{\nu}}{A_{0}}=K=k_{1}, k_{2} \ldots k_{\nu}
\end{aligned}
$$

てたがって

$$
\begin{aligned}
-R T \ln K & =-R T \sum_{\nu=1}^{\nu} \ln k_{\nu} \\
& =-\nu R T \ln K_{0}+\left(F_{\nu}-F_{0}\right)
\end{aligned}
$$

ここで $F_{\nu}, F_{0}$ はそれぞれ $p^{-\nu}$ および $\left(P H_{\nu}\right)^{0}$ 分子の電 気自由エネルギーである。したがって高分子電解質の電 位差滴定の理論は要するに $F_{\nu}$ 女るいは $\Psi_{b}$ の計算に帰 する。

上の説明には高分子酸を用いたが，タンパク質のごと き両性電解質でる問題は全く同一である。(17)式の $\alpha$ は

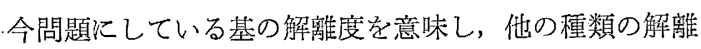
基の影響は $\Delta F_{y}$ のみに含まれる。しかしタンパク質の 場合には (17) (19) 式の代わりに次式が広く使用せられ ている。

$$
P H=P K_{0}-\log \frac{1-\alpha}{\alpha}+0.868 Z w
$$

(22) 式では習慣に従いタンパク質分子の荷電を $Z$ で表
わしたが， $Z$ と(21) 式までのレとは全く同一である。 したがってwが次の内容をるつならば（22）式と (17) 式とは全く同じである。

$$
w=\frac{\Delta F_{\nu}}{2 R T \cdot Z}
$$

多くの理論に和いて $\Delta F_{\nu}$ はりすなわち $Z$ K比例す る量として与えられるゆえ, wは定数として与兄られる のが普通である。

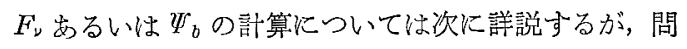
題は要するに, (1) 対イオンの影響をいかに計算するか, (2) タンパク質のイオン吸着を，どのように考慮するか の 2 点にあるかもしれない。鎖状高分子電解質の場合に はこの他に解離度の增大にとるなら分子形状の変化がさ ずかしい問題で女るが, タンパク質ではこの問題は重要 でない。

鎖状高分子電解質に対する $F_{\nu}$ あるいは $\Psi_{b}$ の計算は 多くの人々により行なわれた。たとえば, Katchalsky \& Gillis ${ }^{6)}$ は Kuhn, Künzle \& Katchalsky ${ }^{7}$ の鎖状高分 子イオンモデルを使用し対イオンの効果を無視して計算 し, 後に Katchalsky \& Lifson ${ }^{8)}$ がその理論に対イオン の効果を入れて実際のモデルに近づけた。また Arnold \& Overbeek ${ }^{9 /, 10)}$ は Hermans \& Overbeek ${ }^{11)}$ によっ て計算された糸マリ状高分子イオン内の分子内平均ポテ ンシャルをもって $\Psi_{b}$ とみなした。Katchalsky, Shavit \& Eisenberg ${ }^{12}$ b同様に高分子糸マリ内の平均ポテン シャルが $\Psi_{b}$ になると仮定して解離性と電気泳動を論じ, 桜田, 細野, 伊勢 ${ }^{13)}$ は Hosono \& Ise ${ }^{14)}$ により計算さ れた高分子イオン間相互作用を考慮した $F_{\nu}$ の理論式を 解離汇用いた。そ他 Harris \& Rice ${ }^{15}$ ). 特よび Lifson ${ }^{16)}$ は他と全く異なった立場から高分子イオンに対する対イ オンの吸着のモデルに和きかえて $F_{\nu}$ の計算を行なった。 また Kotin \& Nagasawa ${ }^{17)}$ は解離性には近接解離基の 影響が決定的であることに注目し高分子イオンを棒状モ デルル招きかえて表面ポテンシャル $\Psi_{b}$ を数值計算し実 験と比較した。これら鎖状高分子電解質の解離性に関す る理論拈よび実験に関しては別に述べる機会もあると思 うので, ここでは単形状変化のほとんどないタンパク 質の解離性のみを諭ずることにする。

\section{文献}

1) K. Linderstrom-Lang: Compt. rend. trav. lab. carlsberg, 15, No. 7 (1924); et 文献 2)

2) J. T. Edsall, J. Wyman: "Biophysical Chemistry", 1, Academic Press (New York)

3) C. Tanford: "Physical Chemistry of Macromolecules", (1961) John Wiley and Sons, Inc., (New York)

4) C. Tanford (Editor: T. Shedlovsky): "Electrochemistry in Biology and Medicine", (1955)

(456 ページへつづく) 


\section{5-2. オートラジオグラフィーの応用}

試料中の放射性物質の分布の椂子を原子核畭板を使。 て調べることをオートラジオグラフィーとよんでいる。 これは放射性物質を含んだ試料を乳剤と密着させて適当 な洔間の露出ののちに現像し，これを拡大して観察する。 放射性物質の崩壞によって生じた放射線が乳剤中に入っ て感光作用をして，その放射線に応じて銀粒子を生じ乳 剂が黒化する。黒化の程度によって放射性物質の分布を 詳細に知ることができる。

高分子試料を原子炉で放射化したのち，このオートラ ジオグラフィーを適用寸ることによって不純物の分布状 態を観察することが可能であり，これを実際に応用した 研究もみられ ${ }^{15}$, 今後この方面の発展が期待される。

\section{6. 結言}

高分子分析法としての放射化分析は上述のごとき応用 の途がある。高分子分析法としてはこのほかにも放射性 同位元素を利用した放射化学的分析法の広い応用の分野

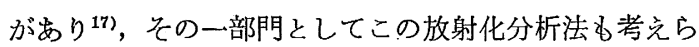
れるものである。放射能を利用する分析化学の進歩は今 後ますますこの方面の発展を促進するものである。

$$
\text { 文献 }
$$

1) G. Hevesy, H. Levi : Kgl. Danske Videnskab Selskab Math-fys. Medd., 14, (5) (1936)

2) G. Hevesy, H. Levi : Kgl. Danske Videnskab
Selskab Math-fys. Medd., 15, (11) (1938)

3) 、嵯峨根遼吉, 江口雅彦, 重田二郎：日数物誌, 16, 383 (1942)

4) G. T. Seaborg, J. J. Livingood: J. Am. Chem. Soc., 60, 1784 (1938)

5) D. T. P. King, W. J. Henderson: Phys. Rev., 56, 1169 (1939)

6) M. V. Ardenne, F. Bernhard: Z. Physik, 122, 740 (1944)

7) R. F. Coleman: Analyst, 87, 590 (1962)

8) R. F. Coleman: Analyst, 86, 39 (1961)

9) H. F. Pfann, D. J. Salley, H. Mark: J. Am. Chem. Soc., 66, 983 (1944)

10) J. Pouradier, A. M. Vent, H. Chateau: Chim. Anal., 35, 125 (1953)

11) W. A. Brooksbank, G. W. Leddicotte, H. A. Mahlman: J. Phys. Chem., 57, 815 (1953)

12) V. P. Guinn, C. D. Wagner: Anal. Chem., 32, 317 (1960)

13）中井敏夫, 岡田 実: 同位体と放射線, 4, No. 1, 66 (1961)

14）武内次夫, 石井大道：日化第 15 年会講演 (1962); 工化投稿中

15）佐藤温吉郎, 鈴木佳枝, 斉藤信房, 西連寺永康： 日化第 15 年会講演 (1962)

16）水池敦, 飯田芳男, 氏平祐輔, 高田芳短: 日本 分析化学会高分子分析委員会講演 (1962)

17) G. M. Kline: "Analytical Chemistry of Polymers", Part III, Interscience Pub., N.Y.-London, 349 387 (1961)
(永沢 満著「タンパク質の解離性」の 445 ページよ りのつづき)

John Wiley \& Sons, Inc. (New York)

5) Y. Nozaki, L. G. Bunville, C. Tanford: $J . A m$. Chem. Soc., 81, 5523 (1959)

6) A. Katchalsky, J. Gillis : Rec. trav. chim., 68, 879 (1949)

7) W. Kuhn, O. Künzle, A. Katchalsky: Helv. chim. Acta, 31, 1994 (1948)

8) A. Katchalsky, S. Lifson: J. Polymer Sci., 11, 409 (1954)

9) J. Th. G. Overbeek: Bull. soc. chim., 57, 252 (1948)

10) A. Arnold, J. Th. G. Overbeek: Rev. trav. chim., 69, 192 (1950)

11) J. J. Hermans, J. Th. G. Overbeek: Rev. trav. chim., 67, 761 (1948)

12) A. Katchalsky, N. Shavit, H. Eisenberg: $J$. Polymer Sci., 13, 69 (1954)

13）桜田一郎，細里正夫，伊勢典夫：高化，15，175 (1958)

14) N. Ise, M. Hosono: J. Polymer Sci., 39, 389 (1959)

15) F. E. Harris, S. A. Rice: J. Phys. Chem., 58, 725 (1954)

16) S. Lifson: J. Chem. Phys., 26, 727 (1957)

17) L. Kotin, M. Nagasawa: J. Chem. Phys., 36, 873 (1962) 